\title{
Public Communication in Totalitarian, Authoritarian and Statist Regimes
}

\section{A Comparative Glance ${ }^{1}$}

\author{
JEAN K. CHALABY
}

\section{Introduction}

This article addresses the following issue: how distinctive was the political communication system that prevailed during the de Gaulle presidency? How democratic was it? To this end, this essay places the French political communication system in a comparative perspective and constructs a typology that contrasts different models, placing the emphasis on the ideology and elite mindset that underpin them. These types comprise totalitarianism, authoritarianism, statism and liberalism.

This article makes two main arguments. Regarding France, it shows that statism, particularly since the de Gaulle presidency, has had a lasting influence on the country's communication system. More generally, it is argued that political communication systems across the world remain fundamentally different from each other, and that the democratic model is better and freer than non-democratic ones.

\section{Typologies of Media Systems}

Over the years, several communication typologies have been developed, none more famous that the one proposed by the authors of Four Theories

1 | An earlier version of this Chapter was published in: Modern \& Contemporary France 13 (3), 273-290. 
of the Press half a century ago. The four models are: authoritarian, Soviet communist, libertarian and social responsibility (Siebert et al. 1963). The first two categories constitute a first cluster, communism being a radical form of authoritarianism, and the last two form another one, the social responsibility model advocating the protection of freedom of expression from the excesses of corporate capitalism. The classic study constituted a landmark in the history of communication studies and started a scholarly tradition of communication typologies (Nerone 1995; Nordenstreng 1997).

In the United States in the early 1970s, Ralph Lowenstein and John Merrill kept the original libertarian and authoritarian categories but replaced 'Soviet communist' with 'social-centralist' (in order to include all the nations of the defunct 'Eastern bloc'), and substituted 'social responsibility' for 'social-libertarian'. A fifth system was added, 'utopian', to underline that none of the existing press systems was perfect (Merrill and Lowenstein 1971). John Merrill subsequently developed his own model, organised in concentric circles converging towards two poles, anarchy and totalitarianism, and including four categories: libertarianism, democratic capitalism (which can deteriorate into state capitalism), democratic socialism (which can degenerate into state socialism) and authoritarianism (Merrill 1974: 40-43). In the following decade, William Hachten kept hold of authoritarianism and communism, widened libertarian into 'Western' and added two categories in order to reflect changes in the developing world.

'Revolutionary' designates press systems that emerge to overthrow regimes, ranging from the French clandestine press during the German occupation and the tracts of the dissidents in the Soviet Union to the newspapers that advocated nationalism and independence in the former colonies. The 'developmental' type occurs where governments of developing nations try to harness the power of communication for purposes of nation-building (Hachten 1996: 13-33). Also in the 1980s, Robert Picard split the globe into two halves, the West and developing nations, applying three and four categories to each zone respectively. In order to incorporate the Scandinavian model of public sphere management, Picard added a 'democratic socialist' category to the initial libertarian and social responsibility concepts. The developing world was divided into authoritarianism, communism and Hachten's revolutionary and developmental types (Picard 1985).

In Europe, typologies have been fewer and far between, probably because the American attempts were seen as ideologically suspicious and 
as by-products of the Cold War. Preference has leant towards the contrasting of ideal types, such as James Curran's 'free-market liberal' and 'collectivist-statist', or Colin Sparks's 'communist totalitarian' and 'bourgeois democracy' (Curran 1991; Sparks and Reading 1998: 35-6). Nevertheless, Raymond Williams in the early 1960s suggested a distinction between authoritarian, paternal (a gentler form of authoritarianism), commercial (market-driven) and democratic communication systems (Williams 1976: 129-137). Denis McQuail's early work stands closest to that of American authors, completing Four Theories with two categories: 'development media' and 'democratic-participant' (McQuail 1983: 8498). This typology was subsequently revised by a collaborative effort led by Kaarle Nordenstreng. The purpose was to adapt normative theories of the press to contemporary trends such as globalisation and the emergence of new media. The authors chose to restrict themselves to democratic regimes, distinguishing five paradigms, or perspectives, that overlap and can co-exist within the same media system: liberal-individualist, social responsibility, critical, administrative and cultural negotiation (Nordenstreng 1997; McQuail 2000: 160-162). More recently, Curran and Park proposed a classification that combines economic and political criteria. Types include 'transitional and mixed societies' (e.g. China and Russia), 'authoritarian neo-liberal societies' (e.g. South Korea and Taiwan), 'authoritarian regulated societies' (e.g. Egypt and Zimbabwe), 'democratic neo-liberal societies' (e.g. Japan and the United States) and 'democratic regulated societies' (e.g. Italy, Sweden and France) (Curran and Park 2000).

Intellectually stimulating as these typologies might be, the amount of criticism levelled against them raises the issue of their purpose. Do they not constitute a naive attempt to comprehend an increasingly complex reality? Are they not condemned to betray an ethnocentric vision of the world media? Much of the answer rests with the manner in which these models are constructed and applied. Three options establish the nature of a communication typology.

A model's internal coherence is determined by the criteria selected to distinguish different types. These criteria need to be limited in number, be made explicit, and applied in a systematic manner across the board. This theoretical underpinning is arguably the analyst's most difficult task and the Achilles heel of many models. A typology scope is set by two possible strategies. The 'tentpoles' route consists in selecting ideal types that constitute benchmarks among a wide array of regimes. Communication systems either constitute 'cases in point' for a partic- 
ular type or can be approximated to these categories and ranged into sub-genres. Those who follow the 'continuum' strategy prefer to avoid gaps between types and try to cover as much ground as possible with the main categories. The authors of Four Theories took the first option, while Hachten or Curran and Park chose the second solution. Finally, the degree of empiricism of a typology is determined by the objects of the comparison. Some models contrast actual regimes while others consider theoretical constructs. In the face of the complexity of contemporary media systems, the trend has been to shift from systems to paradigms. For instance, Nordenstreng and colleagues have decided to contrast different concepts of the press, arguing that 'each national media system and individual media—even each individual journalist—shares more than one paradigm' (Nordenstreng 1997: 9).

The present typology focuses on the political dimension of communication systems, articulating the comparison around two series of criteria. The first set considers the balance of power between state and civil society, and between government and citizenry, and the accountability and visibility of the political elite. The three media-related indicators include the degree of freedom of expression, media independence and media pluralism. This model follows a 'tentpoles' strategy and sets clearly identifiable types around which most regimes can be located. Regarding the degree of empiricism, it contrasts the ideology and elite mindset that underpin a political communication system as much as the systems themselves. However, it is asserted that the political dimension of most media systems falls in or near these types, which remain fundamentally different from each other. It is also argued that these systems can be ranged into a hierarchy according to the criteria set for this typology, and thus that some political communication systems are freer and more democratic than others. The Russian or Egyptian political communication system is not as democratic as the French one, which in turn is not as free as the British or the American ones.

\section{Totalitarianism Fashioning a New Order}

According to Raymond Aron-one of the $20^{\text {th }}$ century's most lucid observers of totalitarianism - the five major characteristics of the totalitarian phenomenon are as follows: 1 . A single party retains the monopoly of political activity; 2 . This party is armed with an ideology on which it 
confers absolute authority and which becomes the state's official truth; 3 . The totalitarian state keeps a monopoly on means of violence and of persuasion, and thus all media are state-controlled; 4. Most professional and economic activities become part of the state apparatus and are suffused with the official ideology; 5 . As all activities are subjected to the official ideology, any mistake committed anywhere becomes an ideological blunder, resulting in a politicisation and 'ideological transfiguration' of all possible mistakes by any individual, in turn leading to physical and ideological terror (Aron 1965: 284-285).

Totalitarian regimes are driven by revolutionary elites, and their beliefs and techniques hold the keys to the role media play in such a system. According to the French philosopher, the three traits that best characterise totalitarian elites are their Machiavellianism, cynicism and violence (Aron 1993: 192-202). Their Machiavellianism involves a pessimistic vision of human nature, an exaltation of action, and an attitude to politics that prompt them to an aggressive amoralism and exclusive will to power. The same political attitude leads totalitarian elites to deploy a range of techniques either to achieve or keep power that include the coup d'état, the destruction of parliamentary democracy, the organisation of a totalitarian party and extensive use of propaganda.

Under such conditions, all personal freedoms are annihilated, including freedom of thought and expression. The media organisations and their workers lose their independence to become the servants of a will to power that subjugates everyone and annihilates all civil society institutions. They become parts of the ideological state apparatus that embraces artistic and film production, the education system, science and religion. In the totalitarian state, the party's monopoly on the means of communication serves two broad purposes. The first is repressive in scope and helps stifle dissent and silence opposition to the party's autocratic rule. Second, it facilitates the transformation of the media into instruments of propaganda designed to indoctrinate the masses. Totalitarian parties engage in vast programmes of socialisation in order to fashion the new individual that fits in the party's vision of the new order.

The media in the defunct Soviet Union, at least during Stalin's rule, provide an archetype. All aspects of the media, from newsprint production, printing plants, newspapers and television channels were state-owned and part of the Communist Party apparatus (Hopkins 1970: 28-31). According to Mark Hopkins, the Soviet press acted as the mouthpiece of the party, conveying the ideology, indicating the latest political orientation 
and publicising the views and decisions of the government and bureaucratic agencies. It did not preclude the occasional and within-limits 'criticism and self-criticism' of the government and the Party (Hopkins 1970: 34). Other tasks for the press included mass mobilisation (newspapers trying to secure support for the incoming industrial and agricultural programmes), and the prescription of the right values and behaviour:

"Accounts in the Soviet mass media of criminal trials, of hooliganism, currency speculation, pilfering, lying, cheating, loafing, drinking, wife beating, profiteering, slandering, and brawling are all lessons in how one should not behave, and Soviet press reports ordinarily are bluntly explicit in saying so. They draw a moral from the tale. In hundreds of redundant reports, the Soviet mass media sketch pictures of the worthy citizen, husband, wife, worker, Communist Party member, collective farm chairman, factory manager, schoolboy, writer, artist, government bureaucrat, and even the national leader" (Hopkins 1970: 41).

Entirely driven by the agenda of the Communist Party, the content of the Soviet media bore little relation to reality. The fundamental flaws of the communist experiment and the countless social issues, from unemployment to prostitution, were strictly off-limits and taboo (see, for example: Vitaliev 1990). The privileges of the elite, their special shops, restaurants, hotels and trains, were never mentioned either. It must have been a strange_-and frustrating — experience to read a Soviet paper, but people had many reasons to buy a newspaper other than reading it.

Totalitarian regimes are largely a $20^{\text {th }}$ century phenomenon, typified by the rules of the Nazi Party in Germany and of Stalin in the Soviet Union. Japan, before and during the Second World War, and China, during the Cultural Revolution, also experienced the traumas of totalitarian rule. The last remaining totalitarian regime is North Korea, to which can be added quasi-totalitarian regimes such as Belarus, Cuba, Libya and Turkmenistan. The leader of the latter country, President Niyazov, has just launched the second instalment of his book at a parliamentary ceremony, obligatory reading for adults every Saturday and for schoolchildren every day.

With the fall of Saddam Hussein disappeared one of the last major totalitarian regimes. The founder of the Baathist movement in the mid$20^{\text {th }}$ century, Michel Aflaq, drew heavily on the principles of the Nazi and Soviet Communist parties (Beeston 2003). Saddam Hussein himself was a great admirer of Stalin and modelled his governance on the Russian dictator. In Russia in the 1970s, he visited every single residence once occupied by the tyrant, from the Kremlin to the numerous villas 
on the Black Sea coast. He was a life-long student of Stalin, on whom he possessed a library of books that had been specially translated into Arabic. He applied the same methods to gain and retain power: unrelenting terror applied first to the party comrades and then to society at large, transforming himself into a mass murderer in the process (SebagMontefiore 2004). As in the Soviet Union, the state-controlled media subjected the Iraqi people to propaganda. State television offered blanket coverage of the numerous commemorative events decreed by the regime in order to rewrite history and glorify its leader. These included the 'Day of the People', 'Flag Day', 'Attitude Day', 'Day of the Noble Call' (celebrating the invasion of Kuwait), 'Science Day' (for the first Scud missile fired at Israel), the 'Day of the Great Victory' (marking the end of the Iran war), the 'Day of the Great March' and Saddam's own birthday, leading to several days of official celebration (Cases 2003: 3-4).

\section{Authoritarianism Keeping the Legitimation Crisis Under Control}

A fundamental difference between totalitarian and authoritarian regimes is that the latter are not revolutionary in character. In fact, authoritarian rulers often justify their methods by invoking the alleged threat from extremist groups. Authoritarian regimes rule conservatively because they are geared towards self-preservation and the protection of the political and financial interests of the clique of cronies that form the entourage of the leader. There is no specific constitutional arrangement for authoritarian regimes, which range from monarchies to presidential regimes and quasi-single-party systems. Some authoritarian regimes try to masquerade as democracies and organise pseudo-elections, but their nature is revealed by the longevity of the leader's rule and his ability to pass on power to his chosen heir.

The media systems that prevail in authoritarian regimes are shaped by the administration's communication needs. Authoritarian rule can never be fully justified - even less today than ever in the past-and thus these governments find themselves in a situation of perpetual legitimation crisis. In order to keep this crisis as latent as possible, they try to control the public sphere and adopt a repressive attitude towards the media. Terror and propaganda may not be as systematic and widespread as under totalitarian rule, but they are deployed with more discernment. Authoritarian regimes last longer because their use of violence-both 
physical and symbolic - is rational and measured to the threat. The same authoritarian regime that may feign magnanimity towards a fringe movement will be ruthless against a significant danger.

It is not rare for these regimes to keep complete control over the broadcasting media, often through state monopoly. Commercial broadcasting companies can exist on the margin of the system but they are usually controlled either by regime cronies or cash-rich state companies from outside the media sector. The press may enjoy more freedom, but remains dominated by official newspapers. When they are allowed, opposition papers are stifled with stringent censorship rules that typically proscribe criticism of the army and government and prohibit any meaningful debate under the pretext of 'state security'. Censorship is rife and exercised through an array of means that range from administrative procedures, subsidies, taxation, intimidation and violence. The judiciary lacks any autonomy and therefore journalists brought before the judges stand no chance of a fair trial. The climate of fear breads self-censorship, despite assurances from the regime that journalists are absolutely free to write what they please.

Censorship keeps criticism at bay, but the government needs to drum up support for a corrupt administration which is out of touch with public opinion and takes decisions that protect the interests of very few people. The official press and its sycophantic journalists are on hand to praise the government and acclaim the leader. The state broadcaster's news bulletins (protocol news followed by sport and weather) relay the good news to the illiterate millions.

While totalitarian regimes try to change the way people think because they might entertain the possibility of establishing a new order, authoritarian elites are driven by greed rather than ideology and simply seek to maintain the status quo. Thus they do not care much about what people think as long as they keep their mouths shut. This explains why the measures taken by authoritarian regimes against the media are not as drastic as under totalitarian rule. Authoritarian media systems are more open to foreign media outlets (as long as their reach is limited) and can replace relentless propaganda with escapism and entertainment. Comedy, soap operas and theatrical drama, while often laden with commissioned propaganda messages, can also provide a safety valve for those who can read between the lines. Media reporting may not diverge from reality as far as it does in a totalitarian system, but authoritarian regimes still function without a proper public sphere. Authoritarian elites are little 
more accountable and have nothing to fear from public opinion and the citizenry: leaders only lose power to plotters who are regime insiders.

Authoritarian regimes are in retreat in Latin America, where a perfect historical illustration is provided by Mexico under the long rule of the Institutional Revolutionary Party from the 1930s to the 1990s (Lawson 2002). Authoritarian rule is still frequent in Africa, however, and constitutes the norm in Central Asia and the Middle East. In the latter region, power is in the hands of a few autocrats, who reign with near absolute power over hapless and destitute people, plundering the resources of their nations and amassing formidable wealth in the process.

\section{Statism \\ Reinforcing the Nation-State}

I have previously defined statism as follows: "the system of thought and the ensemble of actions and decisions that aim at reinforcing the political, legal and symbolic means placed at the disposal of the state in order to strengthen its role and influence in the social and economic life of the nation" (Chalaby 2002: 227). Typical statist policies include inward-looking industrialisation, interference in everyday economic life, a degree of central planning, control over market mechanisms, and widespread state ownership (Wolf 2004: 130-133). These policies flourish under certain conditions, notably during the developmental periods of nations. They are often pursued by regimes that are neither (or no longer) authoritarian nor (or not yet) democratic, such as the Latin American nations in transition from military juntas in the 1970s and 1980s, and several Eastern European countries after the collapse of the Soviet Union in the early 1990s. Statist policies can also be adopted when the ruling class feel that state power, legitimacy and infrastructures need to be strengthened. In addition, the market economy is typically weak and the administration does not wish to (or cannot) embark on a liberalisation programme. This can be due to several factors, including a strong socialist heritage, the presence of powerful left-wing or communist parties, and a sense from the elite that they would lose too much of their power in a liberal economy.

Thus statism can be defined as a mode of governance to the extent that it entails a spectrum of typical policies and is fairly common in nations in transition from authoritarian to democratic rule. Although statism is a doctrine that can be found under several constitutional arrangements, 
these nations often adopt a presidential constitution, which typically entails an elected legislature and a directly elected president in charge of the executive (Linz 1994: 6). This political system aims to create a strong executive by conferring key powers on the president. The ideal-typical statist political communication system presents the following features (allowing for important variations):

1. The state remains a key player in the public sphere and continues to exert strong control over public communications. Broadcasting is either under state monopoly or dominated by a very strong state broadcaster. While the press can be set free, it will be subject to tight regulation. When necessary, the government will not refrain from direct intervention to reassert its influence in times of crisis.

2. Television is mobilised for general nation-building purposes. It is considered a national institution, and the channels of the staterun television are imbued with a certain prestige. They are granted an official character, in politics as in culture. For the newly independent countries, national television is a symbol of sovereignty, like the flag, the national anthem and the seat at the United Nations. Television is also used to promote a national identity, and news and factual programmes must convey an image of the country that fits into the official imagery. History, official ceremonies, achievements in science, sport and diplomacy are evoked to celebrate the nation and bring people together under one banner.

3. Statism does preclude a level playing field in the public sphere, but is not a de facto obstacle to press freedom. Although the government will be the dominant voice in the public sphere, the opposition can have limited access to broadcasting and the press can be free. It is often the case that political parties in opposition compensate for their poor access to television by forging close links with leading and influential newspapers.

4. The signature constitutional arrangement of statist regimes, the presidential system, is a strong incentive for state control over television. By virtue of their powers and status, presidents expect and demand favourable political coverage from the state broadcaster. The outcome is biased reporting, the absence of objective analysis from journalists, and a dearth of public debates between members of the government, the public, journalists and the opposition. News reporting is dominated by protocol news, the footage 
reporting the government's and the president's official activities. In addition, presidents consider as vital to their tenure their ability to establish a direct relationship with the public. They rely on their charisma to create a personal bond with their constituents; state television offers them the guarantee that they can communicate with the electorate above the heads of state dignitaries, journalists and party officials as often as necessary. Finally, control over television is a necessity for the incumbents of powerful presidencies because personal power is always more difficult to legitimise than collegial rule.

Regimes with strong statist overtones (and which have often adopted a presidential constitution) include India during the decades after independence, Latin American nations in transition from military regimes in the 1970s and 1980s, and several Central and Eastern European countries after the fall of communism, such as Croatia during the Tudjman era and the Ukraine under Kuchma. Until recently, Russia fitted perfectly into the statist model. Vladimir Putin had wrestled back control over broadcasting from the oligarchs but had set the press free. Today, the Russian president is using the Beslan disaster to consolidate power in his hands, silence the press, turn the parliament into a rubber-stamping body, revitalise the secret police and curtail regional powers. According to present evidence, it seems that Russia is returning to authoritarianism. France is the country where statist policies have had the most profound influence on the media as well as other fields of activity. The de Gaulle presidency from 1958 to 1969 can be considered the archetypical statist regime, and Gaullism the most sophisticated exposition of the doctrine. Its impact and legacy on France's political communication is examined in the last section.

\section{Liberalism Freedom and Capitalism}

One of the criticisms levelled against the authors of Four Theories is that their models offer different degrees of concreteness: authoritarianism is presented as a set of practices whereas the libertarian model is constructed as a body of theories. Thus it is unclear how tangible is the libertarian ideal-type: "Did 'libertarianism' define the press of the nineteenth-century United States? If so, was it because people (the public, the press, the state) believed in the libertarian theory? Or was it 
because the system (ownership structures, market considerations, legal requirements) was de facto libertarian?" (Siebert et al. 1963: 18-22).

There can be no doubt of the existence of free press systems, such as those that prevail in Britain and the United States. In both countries, a body of laws protects freedom of expression and media organisations against undue political interference. Political elites are accustomed to a free press and expect public scrutiny of their management and criticism of their decisions. Spin doctoring, which seeks to influence media coverage of the government and political parties (see, for example: Cottle 2003), cannot be equated to the means of coercion deployed in other regimes. Politicians have developed news management techniques precisely because they have lost control over the media.

A liberal political communication system is based on legal principles and, above all, a balance of power between two fields: politics and the media. In Britain and the United States, liberal laws and market mechanisms have led to the emergence of a relatively independent press in the course of the $19^{\text {th }}$ century. Progressively, the press emerged out of the shadows of party politics. Newspapers became self-sufficient as their growing income from sales and advertising diminished their reliance on political bribes and subsidies (Aspinall 1949: 66-102). As the relationship between the newspaper and reader became increasingly important, the tone of the press became less partisan and its content depoliticised. Editors expanded news sections, coverage of non-political topics and confined overtly partisan commentaries to editorials (Baldasty 1992). Journalists and reporters acquired new fact-centred discursive practices such as the news report and the interview (Chalaby 1996). By the end of the $19^{\text {th }}$ century, a relatively independent journalistic field had emerged in Britain and the USA. This field has developed its own rules, norms, practices, standards and institutions, set independently from the world of politics (Chalaby 1998).

The relationship between journalists and politicians is that of interdependence. Journalists use politicians as a source of information and politicians need journalists to publicise their views. This relationship involves both collusion and conflicts between the two groups of actors. There can be convergence of interests between journalists and politicians: political correspondents may hope for better access to senior political figures, or their news organisation may pursue some regulatory favours. Politicians need the media to communicate to other elites and their electorate. Conversely, conflicts can arise between the fields of journalism and politics. Journalists can be accused of bias or inaccuracy 
in their reporting, as illustrated by the standoff between the BBC and the British government following allegations made by a BBC reporter about the government's Iraq dossier in May 2003. Politicians also occasionally complain about the quality of political coverage and privacy issues.

Although liberal democracies promote freedom of expression by constantly adapting their regulatory framework, no regime is without issues concerning press freedom. In the United States, public liberties activists are on the alert following several incidents in the run-up to the presidential election, including Disney's decision not to distribute Michael Moore's Farehenheit 9/11 and Warner Bros.' refusal to release an antiwar documentary. The rumours that Disney did not want to anger the Bush family in order to avoid scrutiny of tax issues at its theme park in Orlando, Florida, prompted the trade magazine Variety to comment:

"Just imagine: Lawyers and lobbyists perennially on the qui vive to determine if any marketing gimmick, any news item, any movie, any loudmouth talkshow host could cause trouble in [Washington] D.C., jeopardize a deal in China or hurt cooperation between moguls. Such a scenario of congloms second-guessing themselves at every turn is not so far-fetched" (Guider 2004).

As real as they are, these issues must be placed in context. These instances of censorship receive a high level of publicity but remain isolated. ${ }^{2}$ The side-effects of capitalism and corporate power should not distract us from the liberal foundations of democratic communication systems. In no other model do politicians have so little control over their communication environment. Their acts and decisions are subject to constant scrutiny and they live in the full glare of the public eye. The series of political scandals that have agitated British and American public life over past decades, from the Profumo scandal to the Lewinsky affair, attest to the vulnerability of politicians to public disclosure (Thompson 2000). This stands in sharp contrast to the lack of accountability enjoyed by the political personnel in non-democratic nations, notably due to the absence of media scrutiny. Beyond the controversies over sexual scandals, no other media system guarantees such transparency of decisional and political processes. From a comparative perspective, the openness of a democratic political communication system stands in sharp contrast to the opacity of non-democratic models.

2 | For instance, Disney's decision harmed the media company more than it hurt Moore and did not prevent the documentary from becoming a commercial success. 


\section{Gaullism, Statism and Political Communication}

Modern France illustrates the impact statist policies can have on a political communication system. Such policies were particularly prevalent during the de Gaulle presidency (1958-69), since statism lies at the heart of the Gaullist political doctrine. In the communication field, de Gaulle spurned the chance to liberalise broadcasting twice in the course of his tenure.

Shortly after arriving in power, a first reform approved early in 1959 maintained the state monopoly in broadcasting and the control of the Ministry of Information over the Radiodiffusion-télévision française (RTF). Facing constant criticism, de Gaulle's successive ministers of information were soon pleading with him to let them confer more autonomy on the RTF. Following years of pressure from Alain Peyrefitte-the minister of information he had appointed in June 1962-de Gaulle reluctantly acquiesced to a project of reform towards the end of February 1964. The government forced it through the National Assembly in June 1964 and kept concessions to liberalism to a strict minimum. The law might have changed the name of the state broadcaster to Office de radiodiffusiontélévision française (ORTF), but it maintained the state monopoly and kept the ORTF under the 'tutelage' of the Ministry of Information. The ORTF director was still to be nominated by the Cabinet, who could dismiss him at short notice. Half of the members of the newly created board of trustees were appointed by the Cabinet as state representatives, and none of the other eight members could be appointed without the government's approval. The president of the board, Wladimir d'Ormesson, had been selected by de Gaulle himself on the grounds that he was a 'loyal servant of the State' (Peyrefitte 1997: 175).

These two 'reforms' show the hallmarks of the Gaullist broadcasting policy: state monopoly and governmental control. These policy choices originate in the statist beliefs of de Gaulle and the presidential character of the regime he inaugurated. ${ }^{3}$ Gaullism can be interpreted as the non-socialist version and a French adaptation of a set of beliefs that was common currency in post-war Europe. Time and again, de Gaulle insisted that only a powerful and centralised state could govern for the general interest and face down sectarian political parties, trade unions and lobby groups (see, for example: de Gaulle 1954: 31-36, 86-87; 1959: 14-15, 41, 53, 285-290).

3 | This article focuses on the influence of statism. On the impact of presidentialism, see: Chalaby 2002. 
During his first spell in power, between 1944 and 1946, the French leader (in agreement with the rest of the political class), nationalised energy production (coal, oil, gas and electricity), the banking system, the means of transportation and the main industrial conglomerates (Bernard 1995: 56-58). He created an array of powerful institutions, governmental agencies and regulatory bodies to give the state the means to play a central role in the social, economic and cultural life of the nation. Among these creations figure the Ecole nationale d'administration (ENA), founded in 1945 to homogenise the recruitment and formation of the French political elite, and the Compagnies Républicaines de Sécurité (CRS), the anti-riot police forces (Teyssier 1995; see also: de Gaulle 1959: 330; 1970a: 145-147). ${ }^{4}$ When de Gaulle came back to power in May 1958, he governed France with a similar political mindset and created yet another institution that made the French state more powerful and centralised than ever: the presidency.

In this context, to keep broadcasting under state control was a matter of balance between the private and public sector. When the state is already entrusted with energy production, banking, transport and the manufacture of a variety of products ranging from cars to aeroplanes, it is logical for it to control broadcasting. Gaullism gave the state enough power, competence and responsibilities for the broadcasting media to remain a state institution and the state apparatus was vast enough to incorporate a broadcasting organisation. French television was a cog in a vast and ubiquitous state apparatus that dominated the life of the nation and that of all its citizens.

De Gaulle's statist doctrine comprises an element of dirigism, which dictates that the economy should remain under political control. It was not merely a case of keeping broadcasting in the hands of the state, but also of protecting it from the private sector and market forces. De Gaulle was adamant: "The market is not above the nation and the State. It is the nation and the State that must dominate the market" (Peyrefitte 1994: 524). With such a concept of the relationship between the state and the market, commercial broadcasting could not prosper in France. Entrepreneurs and commercial ventures were perceived as intrinsically

4 | Notwithstanding the fact that the in aftermath of the Second World War there was a large consensus in the political class to give the state a central role in rebuilding the country, these measures fully reflected de Gaulle's innermost ideological preferences. He began to justify these nationalisations during the war, notably in a lecture given at the National Defence Public Interest Committee in April 1942, and in a public address at the Royal Albert Hall, London, two months later. See: de Gaulle 1959: 329; 1970b: 176-181, 197-204. 
alien to the national interest. This left the state with the sole legitimacy to oversee broadcasting and de Gaulle the freedom to choose a role for radio and television.

\section{Television and Nation-Building}

De Gaulle had several tasks in mind for broadcasting. First, he was determined to use the state's mass communication capabilities to restore its authority. He once said: "This establishment [the RTF] should be the voice of the state in France" (Peyrefitte 1994: 98). He detailed his thought to his minister of information in 1962:

"Do you think [says de Gaulle to Peyrefitte] that the Third Republic would have taken root if it had not been forceful, if it had not taken hold of primary education, secondary schools, academia, history textbooks and most newspapers? It imposed a fait accompli on a ruling class which was massively hostile to it: ' $\mathrm{La}$ Gueuse'! The monarchists, then the majority, were divided-as the right wing always is-between three pretenders to the throne: the Orleanist, the Legitimist and the Bonapartist. Thus Thiers concluded: 'It is the Republic that is the less divisive'. For decades, they propounded this theory and impressed it on the popular mind.

The Left, the Freemasons, the unions and the Black Hussards [primary school teachers], obstinately inculcated the idea that there was no other possible regime, that it was a dereliction of civic responsibility to imagine another one, that any adversary to the regime was not a good French citizen. Even so, faced with this opposition, it took the Great War to render the Republic acceptable to almost everybody! Forty-five years after its proclamation! The new regime has been established only three and a half years. It will need much more time to become irreversible!

[...] It is not the moment for a statute for the RTF! By law, you have authority over the institution, its managers, technicians and journalists! Guard this authority! The future of the regime depends to a great extent on the way this authority will be exerted. One never knows what will happen! The time to 'decolonise', as you say, has not come yet!" (Peyrefitte 1994: 497-498).

According to de Gaulle, the Fifth Republic would crumble without the capacity to sustain the ideology needed to gain the adherence of the French people. For the president, the national broadcaster was a state institution in the full sense of the term. Broadcasting policy was not merely about keeping control over television, but about the contribution television could make to the establishment of the regime and the 
restoration of the state as a central and dominant institution in modern France.

Second, de Gaulle wished to use broadcasting to reinforce France's social cohesion. This was an issue of great concern to the French leader, who remained deeply impressed by the divisions that arose between social classes in the late 1930s. He recalled the 'large fractions of the Right' leaning towards Hitler and Mussolini and vividly remembered hearing the commander-in-chief of the French Army hope that the Germans would help him maintain order (de Gaulle 1954: 37, 59, 70, 79). Once at the helm of the country, he had a genuine desire to quell these divisions and make France a united nation again.

A way to promote social cohesion was to bring people together around the idea of the nation, and thus de Gaulle was constant in his effort to foster a French national identity. He promoted the use of national symbols and multiplied the references to national history in his public addresses. He tried to engage the French people with their own nation, and television had a role to play in this effort:

"You know [de Gaulle said to the minister of information in December 1963], television can be an awful or a wonderful thing. Ben Gourion told me that, first, he was opposed to the arrival of television in Israel. He felt that television could distract his compatriots from the construction of their state. While they had to transform the desert into an oasis, enlist people in kibbutzim and in the army, television might lead them to amusement, idleness and laziness. Then, he allowed himself to be convinced that television could be useful in giving a common language and a common culture to Jews coming from all over the world. As long as he held television in his grip, it played this role. But television increasingly slipped from the hands of the state and it started to digress, talk rubbish and criticise for its own sake" (Peyrefitte 1997: 178).

This excerpt best epitomises de Gaulle's broadcasting philosophy. These convictions nurtured his determination to keep control over television and influenced his concept of good programming. This philosophy emanates from the memo below, dated February $18^{\text {th }}, 1963$, in which de Gaulle disparages the broadcast news:

"The news attaches importance to:

- the picturesque (the anecdotal is preferred to the exposition of reality);

- the pessimistic (catastrophes, massacres, crimes, are preferred to what goes well); 
- individualism (the isolated case, particularly if it is malicious or offensive, is preferred to the general interest or the attitude of the majority);

- the opposition (everything that is against the established order and the activities of French public services, inside or outside the country, is preferred to that which is sanctioned, official and national)" (de Gaulle 1986: $318)$.

De Gaulle shows here his refusal to accept the inner logic of news and journalism. While conflicts, disasters and generally unforeseen and exceptional events are always newsworthy, de Gaulle expects broadcast journalists to focus on the normal and the traditional and to accentuate the positive in the life of the nation.

The president applied the same rules to fictional material and historical documentaries. He disliked dramas and history programmes that presented France from an unorthodox point of view. During a strike of ORTF producers in February 1965, de Gaulle instructed the minister of information to take advantage of this industrial action "to get rid of this mafia at last" (Peyrefitte 1997: 180):

"We should not let ourselves be impressed by their alleged talent! In reality, these people are decadent. They always present the catastrophic, pathetic and deplorable side of things. It is a tendency that has always characterised decadent people! One has to prevent them from indulgently showing the pathological rather than the healthy, the sluggish rather than the striving, failures rather than successes, the shames of history rather than its glories! These men show interest only in the ugly and the sensational" (Peyrefitte 1997: 180)

De Gaulle used to say that 'there is only one history of France and only one people of France' (Peyrefitte, interview with author, May $4^{\text {th }}, 1999$ ). and demanded that television programmes convey a similar vision of the nation. He was incensed when programme makers approached their subjects from an anecdotal or sensationalist angle. For instance, he reproached Stellio Lorenzi for presenting Louis XIV as if the only interesting fact about the French monarch was that he changed mistresses about every evening, "without taking into account the grandeur he gave to France, nor the influence and prestige of the nation in Europe and the world during his reign" (Peyrefitte, interview with author, May $4^{\text {th }}$, 1999). De Gaulle and his followers strove for a national television, capable of strengthening national identity and reinforcing the emotional and ideological foundations of the nation. 


\section{Conclusion}

Scholars who compare democratic and non-democratic regimes often level off differences between communication systems and sometimes reserve their sharpest criticisms for the impact of 'evil' corporate capitalism on the public sphere. Colin Sparks, who accuses the authors of Four Theories of gross distortion and 'ideological warfare', spends the rest of his book playing down the differences between the communist and capitalist media systems (Sparks and Reading 1998: 54). Like the communist press, the British press is 'partisan' and its readership 'class-stratified', and the US press 'generally operates in a monopoly situation' (Sparks and Reading 1998: 176). The same agenda dictates the choice of contributions in Curran's and Park's edited collection. While some of their contributors strive to find virtues in the most oppressive regimes-notably Egypt and Zimbabwe-W. Lance Bennett jumps on the opportunity to argue that the American media are mostly about 'the production and reproduction of power' (Bennett 2000: 205). In Last Rights, John Nerone and colleagues rightly address some the inconsistencies and inadequacies of Four Theories, but mostly blame the authors for their bias in favour of liberalism. The nature of power in liberal and capitalist societies, the authors contend, is not merely political but is also economic in character:

"The libertarian theory, as Four Theories constructs it, assumes that in the absence of state control, the media are free, that deregulation (or non regulation) necessarily coincides with liberty, and that the state is the only possible source of obstruction to media operation. What is troubling about this reasoning is that it does not concede even a theoretical benefit from rules a democratic government may enact and, much more importantly, it does not acknowledge that there are sources of control other than the state, notably the 'free market' itself. [...] A truly free press would be free not just of state intervention but also of market forces and ownership ties and a host of other material bounds" (Nerone 1995: $22,24)$.

This argument, frequently voiced by the British political economy tradition, can be sourced to Raymond Williams, who opposed the 'commercial' communication system to the 'democratic' one, on the grounds that "commercial control of what can profitably be said [...] also can be a tyranny" (Williams 1976: 133). A central supposition of this viewpoint needs to be assessed. It is asserted that democratic and capitalist systems exchange a set of political constraints for commercial restrictions. The press might be nominally free in democracies, but the concentration 
of ownership and the search for profit enslave newspapers to market forces and put them right back in the hands of the dominant class. All things considered, there is little difference between the Soviet Pravda and the New York Times, since both repeat the mantras of their respective dominant ideology and, in fine, serve the purpose of the local political elite.

As this paper has begun to show, a democratic framework is a sine qua non on which freedom of expression rests, and arguably all other liberties. Democratic communication systems remain much freer than those in non-democratic regimes. The issues they face are of a secondary order compared with those confronting the media in other political regimes. Corporations might have a significant presence in democratic media systems, but it is the challenge of regulatory agencies to check corporate power and make markets work for the public sphere.

It is time that we faced the inescapable truth that not all political communication systems are equal. All public spheres are not equally open and all political elites are not evenly accountable. Neither are these elites equally competent, nor do they hold the same values: some are more self-serving and corrupt than others. It is a shocking paradox that the minimising of the differences between democratic and non-democratic communication systems is often driven by the very parochial political agenda of those who have issues with their own media: they use comparative media studies to underline the alleged dangerous effects of capitalism on the democratic public sphere. Radical chic theorists underestimate the fundamental differences between democratic and non-democratic media systems, and the advantages of the latter over the former. They also underestimate the damages caused by poor governance, the misery inflicted on millions by inept and unscrupulous elites, and the suffering of those who have to endure the devastating effects of autocratic regimes. 


\section{References}

Aspinall, A. 1949. Politics and the Press. c. 1780-1850. London: Home and Van Thal.

Aron, R. 1965. Démocratie et totalitarisme. Paris: Gallimard.

Aron, R. 1993. Machiavel et les tyrannies modernes. Paris: de Fallois.

Baldasty, G. J. 1992. The Commercialization of News in the Nineteenth Century. Madison: University of Wisconsin Press.

Beeston, R. 2003. Nation ruled by a corrupt vision of Arab unity. The Times (March 31 ${ }^{\text {st }}$ ): 10.

Bennett, W. L. 2000. Media Power in the United States. In De-Westernizing Media Studies, edited by J. Curran and M.-J. Park, 202-220. London: Routledge.

Bernard, F.-C. 1995. Les Nationalisations dans la pensée de Charles de Gaulle. Espoir 103: 56-8.

Cases, S. 2003. The Iraqi Media. 25 Years of Relentless Repression. Paris: Reporters without Borders.

Chalaby, J. 1996. Journalism as an Anglo-American Invention. A Comparison of the Development of French and Anglo-American Journalism, 1830s-1920s. European Journal of Communication 11 (3): 303-326. Chalaby, J. 1998. The Invention of Journalism. Basingstoke: Macmillan; New York: St Martin.

Chalaby, J. 2002. The de Gaulle Presidency and the Media: Statism and Public Communications. Basingstoke: Palgrave.

Cottle, S. editor. 2003. News, Public Relations and Power. London: Sage. Curran, J. 1991. Rethinking the Media as a Public Sphere. In Communication and Citizenship. Journalism and the Public Sphere in the New Media Age, edited by P. Dahlgren and C. Sparks, 27-57. London: Routledge.

Curran, J. and M.-J. Park. 2000. De-Westernizing Media Studies. London: Routledge.

De Gaulle, C. 1954. Mémoires de guerre. Volume 1. L’Appel, 1940-1942. Paris: Plon.

De Gaulle, C. 1959. Mémoires de guerre. Volume 3. Le Salut, 1944-1946. Paris: Plon.

De Gaulle, C. 1970a. Discours et messages. Volume 3. Avec le Renouveau, mai 1958-juillet 1962. Paris: Plon.

De Gaulle, C. 1970b. Discours et messages. Volume 1. Pendant la Guerre, juin 1940-janvier 1946. Paris: Plon. 
De Gaulle, C. 1986. Lettres, notes et carnets, janvier 1961-décembre 1963. Paris: Plon.

Guider, E. 2004. Media Congloms Muzzling Dissent? Variety (6-12 September): 7 .

Hachten, W. A. 1996. The World News Prism. Changing Media of International Communication ( $4^{\text {th }}$ Edition). Ames: Iowa State University Press.

Hopkins, M. W. 1970. Mass Media in the Soviet Union. New York: Pegasus. Lord Hutton. 2004. Report of the Inquiry into the Circumstances Surrounding the Death of Dr David Kelly C.M.G. London: H. M. Stationery Office.

Lawson, C. H. 2002. Building the Fourth Estate. Democratization and the Rise of a Free Press in Mexico. Berkeley: University of California Press.

Linz, J. J. 1994. Presidential or Parliamentary Democracy. Does it Make a Difference? In The Failure of Presidential Democracy. Volume

1. Comparative Perspectives, edited by J. J. Linz and A. Valenzuela, 3-87. Baltimore: John Hopkins University Press.

McQuail, D. 1983. Mass Communication Theory. An Introduction. London: Sage.

McQuail, D. 2000. McQuail's Mass Communication Theory (4 $4^{\text {th }}$ Edition). London: Sage.

Merrill, J. C. 1974. The Imperative of Freedom. A Philosophy of Journalistic Autonomy. Hastings House.

Merrill, J. C., and R. L. Lowenstein. 1971. Media, Messages, and Men. New Perspectives in Communication. New York: David McCay.

Nerone, J. C., editor. 1995. Last Rights. Revisiting Four Theories of the Press. Chicago: University of Illinois Press.

Nordenstreng, K. 1997. Beyond the Four Theories of the Press', Paper Presented at the Media \& Politics International Conference, Brussels, March.

Peyrefitte. A. 1994. C'était de Gaulle. Volume 1. Paris: de Fallois/Fayard. Peyrefitte. A. 1997. C'était de Gaulle. Volume 2. Paris: de Fallois/Fayard. Picard, R. 1985. The Press and the Decline of Democracy. The Democratic Socialist Response in Public Policy. Westport, Conn.: Greenwood Press.

Sebag Montefiore, S. 2004. Stalin and Saddam: the twin tyrants. The Sunday Times (4 July): 9.

Siebert, F. S., T. Peterson and W. Schramm. 1963. Four Theories of the Press. Chicago: University of Illinois Press. 
Sparks, C. and A. Reading. 1998. Communism, Capitalism and the Mass Media. London: Sage.

Teyssier, A. 1995. Le Général de Gaulle et la création de l'ENA. Espoir 103: 31-37.

Thompson, J. B. 2000. Political Scandal. Power and Visibility in the Media Age. Cambridge: Polity Press.

Vitaliev, V. 1990. Special Correspondent. Investigating in the Soviet Union. London: Hutchinson.

Williams. R. 1976. Communications. Harmondsworth: Penguin.

Wolf, M. 2004. Why Globalization Works. New Haven: Yale University Press. 
